\title{
A Value Added Tax and Factors Affecting Its Economic Impact*
}

\author{
by CHARLOTTE E. RUEBLING
}

A

VALUE ADDED TAX (VAT) has at times been mentioned as a substitute for an existing tax or as a source of new revenues in the United States. While a VAT is not currently used in this country, it is employed by many U.S. trading partners in Europe.

One purpose of this article is to provide a general description of a VAT. A second purpose is to point out that some consequences often expected as the result of adopting any tax are conditioned by aspects of the economic environment which can vary from time to time. For example, discussions of a VAT have centered on its possible effects on prices, income distribution, economic growth, and the balance of payments. To evaluate adequately the consequences of a VAT or any other tax, circumstances such as the use of revenues and accompanying monetary developments must be considered.

\section{FEATURES OF A VAT}

\section{The Concept of Taxing Value Added}

A tax often takes its name from the base on which it is computed. For example, personal income taxes are levied against a base of personal income, and retail sales taxes are a proportion of final sales. Value added taxes are no exception, being levied, in principle, on the value of newly produced goods and services.

"The author appreciates helpful comments provided by Professor Charles $W$. Meyer on an earlier draft of this article.

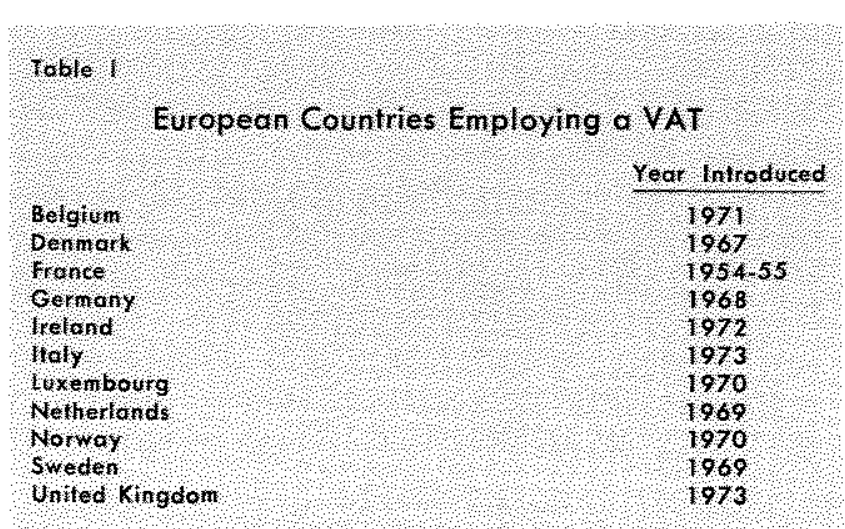

Value added for a given period is conceptually equivalent to all income - wages and salaries, rent, interest, and profits - generated in the production of aggregate output. A VAT nevertheless differs from a general tax on incomes in that firms, rather than the individuals who ultimately receive income, are responsible for paying the tax to the government.

A VAT is often considered to be essentially a retail sales tax. However, a VAT differs from a retail sales tax in that it is collected at each stage of the production and distribution process, not solely at the stage where a product is sold to the consumer.

\section{Methods of Computing a $\mathrm{VAT}$}

There are three methods for computing an individual firm's VAT. These are the addition, the subtrac- 
tion, and the credit or invoice methods. The addition and the subtraction methods involve different approaches to computing the tax base. The credit method calculates the tax liability itself, without requiring explicit measure of a firm's value added. In practice these three computational procedures are only approximately equivalent. ${ }^{1}$

The addition method of computing the VAT base is to sum the firm's payments of wages, salaries, interest, rent, and profits. These payments represent the firm's contribution to the value of the economy's output in the period, or its "value added," This base multiplied by the tax rate indicates the amount owed the government in value added taxes. The subtraction method computes each firm's value added as sales less purchases of material inputs from other businesses. The credit method computes the tax by applying the tax rate to sales and then subtracting taxes paid on purchases of components. Value added taxes in Etropean countries are usually computed by the credit method.

\section{The Treatment of Capital}

Three variations of VAT also arise through different treatments of capital goods. The variations described here are in terms of the subtraction method of computing the VAT base. A gross product type VAT does not allow purchases of capital goods to be subtracted from a firm's sales to determine its tax base. Any part of the VAT assessed to the capital producer's value added which he is able to pass on as a higher price is not recoverable by the purchaser through a tax base reduction matching the purchase price of the capital.

An income type VAT reduces the firm's tax base in each period by the amount of its capital depreciation in that period or by some proportion of the capital purchase price. This type is analogous to net national product, a measure of output which subtracts capital consumed or used-up in producing the gross output or "value added" for the period.

A consumption type VAT excludes from the tax base the entire amount of capital expenditures in the tax period. ${ }^{2}$ This type is somewhat more favorable, or

1See Alan A. Tait, Value Added Tax (London: MoGraw-Hill, 1972), pp. 1-5.

2Norman Ture maintains that this variation has been misnamed. The name promotes the view that it is a tax exclusively on consumption. His analysis develops the proposition that under certain conditions, this type of VAT is a propor tional tax on incomes of owners of productive facilities in the forms of both labor ard capital. Savers, who directly or indirectly are owners of capital, do not escape the tax, because value added by capital is subject to the tax. For a less unfavorable, to investment expenditure than the other two." The total dollar amounts of tax base reductions are ultimately the same under both the income and consumption types. However, under the consumption type, the firm purchasing capital obtains a reduction of the base in the period in which the capital is purchased. With the income type, the reduction is spread over the depreciation period. Thus cash available to the firm in the early years of the capital's use is greater than under the income type. In general, European countries have adopted the consumption type.

\section{Rate Variations and Exemptions}

Many VAT systems can be described as having a basic rate, special rates for some goods and services, and exemption status for certain economic activities or specific goods and services. ${ }^{4}$ These features influence the nation's aggregate effective tax base.

In language used with a VAT, to be "exempt" means that there is no tax payable on sales and that taxes paid on purchases in order to provide a good or service are not recoverable from the government. Various categories of economic activity have been exempted in European countries either to simplify administrative procedures, as when very small businesses are exempted, or to achieve special effects on prices and the distribution of real income in the economy. Banking and financial institutions offer services to which the value-added concept is generally difficult to apply; consequently, these firms and services are commonly exempted from a VAT. Government and educational services, medicine, transportation, and communications products and services are also

given interest rate, the tax on the goods produced with capital raises the amount of net income firms must derive from a capital asset in order to justify its purchase. In other words, the tax reduces the demand for funds, and other things remaining the same, the interest earned by savers. See Charles F. McLure, Ir., and Norman B. Ture, Value Added Tax: Two Views (Washington, D.C.: American Enterprise Institute for Public Policy Research, Novernber 1972), pp. 88-92.

"See Carl Shoup, "Theory and Baekground of the Value Added Tax." National Tax Association Proceedings of the Forty-Eighth Annual Conference, 1955, pp. 11-18, for explanation of an "interest-exclusion variant" of the income type which is equivalent to the consumption type. Also displayed is a proof demonstrating that the consumption type does not discriminate in favor of or against capital as opposed to a situation of no tax.

4See Tax Policy (October-December, 1972) especially the selections: B. Kenneth Sanden, "The Value-Added Tax What It Is; How It Works - Experience in Foreign Countries," pp. 1-19; John S. Nolan, "How VAT should Operate in the United States," p. 20-26; William 1. Stoddard, "Effect of VAT on Service Industries," pp. 59-65; and Gordon Ensley, "The Value-Added Tax and Financial Institutions," pp. $72+78$. 
often exempted. In some countries these and/or other goods and services, considered "necessities," are in. stead taxed at a rate lower than the basic rate, while some items, defined as luxury goods, are taxed at rates higher than the basic rate.

If a firm's sales are subject to a "zero" or "nil" rate, then not only are sales free from tax liability, but the firm also is entitled to a refund of taxes listed on the invoices of purchased inputs. Exports are typically subject to a zero rate in VAT laws and proposals. The zero rate means that exporters do not pay tax on their sales abroad and receive refunds for taxes paid on purchases.

\section{ISSUES CONCERNING THE FRTECTS OF A VAT}

The consequences of adoption of a VAT, or any tax change, for inflation, income distribution, resource allocation, economic growth, and a nation's balance of payments depend on the specific form of the tax and the accompanying circumstances. This section of the paper describes possible effects of a VAT, noting some of the specific aspects of the tax and some of the conditions in the economy which must be considered in order to reach valid conclusions about whether those effects will or will not follow the imposition of the tax. The general categories of considerations discussed are relevant for analysis of the effects of any tax change, not merely one involving a VAT.

One inevitable change in circumstances accompanying any tax change and bearing on subsequent economic developments is the possible use of new revenues. New tax revenues may be used by the government: (1) to purchase goods and services; (2) to reduce or replace another $\operatorname{tax}$; (3) to retire outstanding debt; or (4) to hold balances in commercial or central banks.

Monetary conditions also influence the effects somem times associated with tax policy. Monetary policy and tax policy are often considered separately from each other. Commentators assessing the impact of one or the other often implicitly assume definitions of these terms which keep them distinct. One should keep in mind, however, the following relationships between monetary and tax policy. A decline in money can result from one use of tax revenues - increasing Treasury balances in commercial or Federal Reserve Banks. Also, increases in the money stock can finance government expenditures. Additionally, changes in the money stock have influences over objectives which tax policy often considers - namely, those relating to inflation, economic growth and stability, income distribution, and the international balance of payments. While monetary policy and the government budget are not the only influences on these matters, both are significant.

\section{Inflation}

The possibility of increases in the average price of goods and services upon enactment of a VAT has been a concern of Europeans, even though for some countries the VAT replaced a similar tax known as a turnover tax. For example, in the past year France reduced its VAT rates, along with other measures, reportedly for the purpose of combatting inflation.

Imposition of a VAT or a change in any tax rate, by itself, cannot be considered inflationary or deflationary. Even if sellers were able to raise prices to cover the tax they pay, this would constitute a onetime increase in their prices, but would not necessarily lead to inflation, which is a continuous increase in the average of prices over time.

Even associating a one-time increase in the level of prices with a tax change would be accurate only under special circumstances. A tax on a single good could often be expected to raise the price of that good and perhaps affect prices of related goods and services. ${ }^{5}$ However, a rise in the general price level cannot be maintained unless there is a rise in the dollar amount of goods and services demanded relative to output. Assuming no decline in output, this would require either expansion in the money stock or decline in the public's holdings of real money balances. ${ }^{6}$ If there were neither a rise in the money stock nor an increase in the rate of money turnover, buyers would be unable to make all of their previous purchases at higher prices. A result of a widespread attempt to raise prices would be reduction in the real amount of goods and services sold, rollbacks in some prices, and/or adjustments in production and employment. Consequently, if a rise in the price level is sustained with the imposition of a VAT or other tax change, it is largely because of one or more of the following: the tax has induced the monetary authori-

5For a formal analysis, see Armen A. Alchian and William R. Allen, University Economics, 3rd edition (Belmont, California: Wadswoth Publishing Company, Inc, 1967), pp. $324-328$.

"In the framework of the quantity equation, $\mathrm{MV}=\mathrm{PT}$, familiar to some readers, the reduction of average cash balances is equivalent to a rise in transactions velocity (V) which, in the presence of constant money stock (M) and full employment (constant $T$ ), would produce a rise in prices $(\boldsymbol{P})$. 
ties to increase the money stock; the tax has induced the public to attempt to reduce their holdings of money balances; or the tax has acted as a disincentive to production.

\section{Tncome Distribution}

Many believe a VAT to be a regressive tax - one which takes a larger proportion of lower incomes than high ones. An appropriate analysis of the effects of a tax on income distribution requires consideration of the specific form of the tax - including its rates and exemptions - and the use of the revenues, Consideration of how these in turn affect income distribution is rather complex.

To illustrate, Great Britain replaced selective employment and special purchase taxes with a VAT, effective April 1, 1973. This VAT has a basic rate of 10 percent and a zero rate on some items, including food, housing, fuel, power, and passenger transport. Under the special purchase taxes which were replaced, some luxury items were taxed at a rate of 25 percent while many items purchased more universally were taxed at rates lower than 10 percent. The effect of this tax substitution on income distribution is contingent on how prices of commodities respond to the elimination of one tax and the imposition of the other. The substitution would usually be considered regressive if prices of items purchased predominately by lower income households rise relative to prices of purchases made by higher income households. The assumption, often made, that prices respond in direct proportion to the tax change is usually unwarranted ${ }^{7}$

The income distribution effect of adoption of a consumption type VAT in the U.S. would depend on a number of circumstances including, of course, its rates and exemptions. The use of revenues - for example, whether they were used to reduce or eliminate corporate income taxes, social security taxes, or property taxes, or whether they were used to increase government spending - would help determine the distribution of real income after the tax change. In addition, accompanying monetary conditions would influence the behavior of prices, which, in turn, affects the distribution of real income.

\section{Economic Growh}

One objective apparent in discussions concerning taxation is that the tax system encourage or at least not impair the economy's potential for and achievement of economic growth. What, then, are some of

TAlchian and Allen, pp. 324-328. the possible consequences of a VAT on growth? Once again it depends to some extent on the policy actions accompanying the VAT and responses to these actions. In general we need to ask whether the private sector responds to a given tax substitution or increase by: (1) reducing consumption; (2) reducing investment; or (3) increasing the supply of productive resources to the market. Response (3) appears conducive to growth. However, for the growth impact of response (3) to be lasting, there must be balance between demand and the resulting increase in the supplies of goods. Slack in demand resulting in accumulations of unsold goods is a signal for a production cutback (and/or a price decline) in a market economy. In general, policies conducive to growth are those which increase supplies of productive resources and investment and those which foster conditions in which an essential balance between aggregate supplies and demands can be maintained.

The combination of responses $(1),(2)$, and (3) to adoption of a VAT is influenced by how the VAT, the accompanying use of funds, and monetary conditions affect prices of current versus future consumption ${ }^{8}$ and the conditions which lead resource owners to hold or release their resources to the market. If monetary conditions (rates of money stock growth and money turnover) do not change, relative prices will reflect the impact on prices of the tax for which the VAT was substituted or the spending undertaken by the government. A lowering of the relative price of future consumption would in many circumstances be conducive to growth of production in the economy.

\section{Balance of Rayments}

A VAT, as opposed to some other taxes, is consid. ered advantageous to an individual country's balance of trade. Provisions of the General Agreement on Tariffs and Trade (GATT) foster this effect. GATT permits a rebate of indirect taxes, such as a VAT or sales tax, on exports so that the destination price of the export will exclude the tax, but does not permit the effect of direct taxes, such as the corporate income tax, to be excluded from the export price. In addition, GATT allows a border tax on imports equivalent to the importing country's indirect tax. If direct taxes have a positive effect on the prices of commodities, which is reversed with elimination of the tax, the

8 Future consumption implies saving and buying capital which will yield a larger stock of consumption goods at some time in the future than one is capable of acquiring in the present. Interest rates, influenced by physical productivity of capital and monetary conditions, measure the trade-off between present versus future consumption. 
substitution of an indirect tax, such as a VAT, for a direct tax would tend to increase a nation's exports and reduce its imports, given that other factors affecting trade remain substantially the same. This is because the price to foreigners could be more attractive within a framework imposing a VAT than one involving a direct tax.

\section{SUMMA}

This article has discussed the concept of a value added tax. Its main purpose, however, has been to illustrate some of the necessary, but often overlooked, ingredients for analysis of any tax proposal. To analyze the consequences of any tax change, the accompanying monetary conditions and the change in the amount of one or more of the possible uses of the revenues must be considered.

Two basic points made in this article are: (1) the consequences for income distribution, economic growth, and the international balance of payments of a VAT substitution in the tax structure depend largely on what happens to prices; (2) the effects on prices of the imposition of a VAT in place of another tax depend to a considerable extent on monetary conditions - the rate of growth of the money supply and the velocity of money - and on the price-impact of an alternative tax or other use of funds. In contrast to some widely alleged consequences of a VAT, it is noted that a VAT need not be followed by inflation or greater inequality of income distribution.

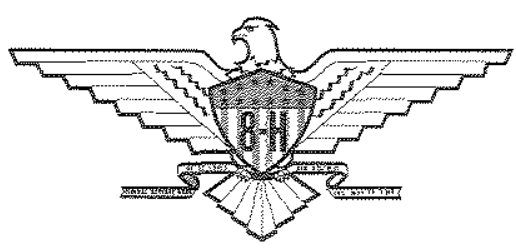

